\title{
Increase of multi-metal tolerance of three leguminous plants by arbuscular mycorrhizal fungi colonization
}

\author{
Ai-Jun Lin $\cdot$ Xu-Hong Zhang $\cdot$ Ming-Hung \\ Wong $\cdot$ Zhi-Hong Ye $\cdot$ Lai-Qing Lou $\cdot$ \\ You-Shan Wang $\cdot$ Yong-Guan Zhu
}

Received: 27 March 2007 / Accepted: 11 July 2007 / Published online: 12 September 2007

(C) Springer Science+Business Media B.V. 2007

\begin{abstract}
A greenhouse pot experiment was conducted to investigate the effects of the colonization of arbuscular mycorrhizal fungus (AMF) Glomus mosseae on the growth and metal uptake of three leguminous plants (Sesbania rostrata, Sesbania cannabina, Medicago sativa) grown in multi-metal contaminated soil. AMF colonization increased the growth of the
\end{abstract}

A.-J. Lin

Department of Environmental Science and Engineering, Beijing University of Chemical Technology, Beijing, 100029, PR China

A.-J. Lin $\cdot$ M.-H. Wong $(\bowtie) \cdot$ L.-Q. Lou Croucher Institute for Environmental Sciences, Hong Kong Baptist University, Hong Kong, PR China

e-mail: mhwong@hkbu.edu.hk

\section{A.-J. Lin · Y.-G. Zhu ( $₫)$}

Research Center for Eco-environmental Sciences, Chinese Academy of Sciences, Beijing, 100085, PR China

e-mail:ygzhu@rcees.ac.cn

X.-H. Zhang

Beijing City University, Beijing, 100083, PR China

Z.-H. Ye

State Key Laboratory for Bio-Control, School of Life Science, Sun Yat-sen (Zhongshan) University, Guangzhou, 510275, PR China

Y.-S. Wang

The Institute of Plant Nutrition and Resources, Beijing Academy of Agriculture and Forest, Beijing, 100089, PR China legumes, indicating that AMF colonization increased the plant's resistance to heavy metals. It also significantly stimulated the formation of root nodules and increased the $\mathrm{N}$ and $\mathrm{P}$ uptake of all of the tested leguminous plants, which might be one of the tolerance mechanisms conferred by AMF. Compared with the control, colonization by G. mosseae decreased the concentration of metals, such as $\mathrm{Cu}$, in the shoots of the three legumes, indicating that the decreased heavy metals uptake and growth dilution were induced by AMF treatment, thereby reducing the heavy metal toxicity to the plants. The root/shoot ratios of $\mathrm{Cu}$ in the three legumes and $\mathrm{Zn}$ in $M$. sativa were significantly increased $(P<0.05)$ with AMF colonization, indicating that heavy metals were immobilized by the mycorrhiza and the heavy metal translocations to the shoot were decreased.

Keywords Sesbania $\cdot$ Medicago sativa $\cdot$ Glomus mosseae $\cdot$ A. caulinodans $\cdot$ Heavy metals

\section{Introduction}

Metal contamination of soils and the subsequent uptake by plants constitute a major environmental problem in some areas of China. Soil contamination by heavy metals is derived from various sources, such as atmospheric deposition, the use of sewage sludge in agricultural land, and the exploitation of mineral resources. An important part of China's sus- 
tainable development strategy is the ecological restoration of contaminated soils, especially those contaminated by mine tailings (Gao et al. 1998), and re-vegetation is a key measure in this restoration (Tordoff et al. 2000; Wong 2003). However, plant establishment and growth in metal-contaminated sites are inhibited by adverse soil factors, such as acidity, poor physical structure, toxic metals, and nutrient deficiencies (Pichtel and Salt 1998; Wong 2003).

Nitrogen $(\mathrm{N})$ is one of the most important nutrients for plant growth. The lack of $\mathrm{N}$ and inhibition of $\mathrm{N}$ uptake induced by heavy metals have a strong impact on plant growth. Therefore, plants that can accumulate more $\mathrm{N}$ may grow better in contaminated soil. Leguminous plants have advantages in $\mathrm{N}_{2}$-fixing by formation of root nodules (Ma et al. 2006). However, their root nodules may be inhibited by heavy metals in the soil, and thus the $\mathrm{N}_{2}$-fixing ability of leguminous plants may be hindered. Medicago sativa (Alfalfa) was found to grow in soils contaminated by heavy metals since it can accumulate metal concentrations above the tolerance levels of most plants (Tiemann et al. 1999). Sesbania species such as Sesbania rostrata and Sesbania cannabina can also grow in soil contaminated by heavy metals (Ye et al. 2001b). S. rostrata, native to tropical West Africa, is an annual species that bears stem as well as root nodules and is associated with Azorhizobium caulinodans, a specialized fast-growing strain of Rhizobia that can fix $\mathrm{N}_{2}$ in its free-living form (Ye et al. 2001b). Unlike root nodules, stem nodules do not make direct contact with the soil and are therefore less susceptible to the stresses imposed on root nodules by toxic mine tailings, thus providing more $\mathrm{N}$ for seedling growth (Yang et al. 1997). For this reason, $S$. rostrata has been used as green manure in crop rotation systems and for the phytoremediation of metal-contaminated soils (Yang et al. 1997; Ye et al. 2001a). Chan et al. (2003) reported that Sesbania plants, such as $S$. rostrata, S. sesban, $S$. cannabina, and $S$. grandiflora, can be used in the remediation of $\mathrm{Pb} / \mathrm{Zn}$ and $\mathrm{Cu}$ mine tailings. Yang et al. (1997) and Ye et al. (2001b) concluded that $S$. rostrata is effective in reclaiming soils contaminated with $\mathrm{Cu}, \mathrm{Zn}, \mathrm{Pb}$, and $\mathrm{Cd}$. However, their studies did not investigate possible roles of arbuscular mycorrhizal fungi (AMF). AMF can enhance plants' tolerance to metal and are often used in the restoration of metal-contaminated sites (Liu et al. 2005; VogelMikuš et al. 2005). A number of studies have indicated that mycorrhizas can assist pioneer plant species to colonize metal-contaminated sites by improving the plants' phosphorus (P) uptake and subsequently enhancing their growth (Smith and Read 1997; Karandashov and Bucher 2005; VogelMikuš et al. 2005).

It was reported that $\mathrm{P}$ is a critical element in forming nodules (Toro et al. 1998). Therefore, the study was aimed to investigate whether AMF colonization could enhance the formation of nodules, increase $P$ and $\mathrm{N}$ uptake, and increase multi-metal tolerance of leguminous plants (including S. rostrata, S. cannabina, and M. sativa).

\section{Materials and methods}

Growth medium

The field soil (paddy soil) used in the present study was collected from Fuyang, Zhejiang Province, China. The soil was sampled from the surface layer $(0-20 \mathrm{~cm})$ of cultivated fields that were contaminated by wastewater from local smelting factories containing high concentrations of $\mathrm{Cd}, \mathrm{Cu}, \mathrm{Zn}$, and $\mathrm{Pb}$. The soil was sieved to pass through a $2-\mathrm{mm}$ mesh, autoclaved $\left(121^{\circ} \mathrm{C}, 2 \mathrm{~h}\right)$ to eliminate indigenous $\mathrm{AMF}$, and air-dried. The soil pH (soil:water $=1: 2.5$ ) was 6.3 before sterilization. The soil was digested with conc. $\mathrm{HNO}_{3}$ and conc. $\mathrm{HCl}(1: 3, \mathrm{v} / \mathrm{v})$ at $160^{\circ} \mathrm{C}$ for $48 \mathrm{~h}$, and the concentrations of $\mathrm{Cu}, \mathrm{Zn}, \mathrm{Pb}, \mathrm{Cd}$, and $\mathrm{P}$ in the solutions were determined by inductively coupled plasma-atomic emission spectroscopy (ICP-AES) (Cui et al. 2004). A standard soil material (NIST 2711 Montana Soil) was used to verify the acid digestion method used in this study. The recovery for all trace metals in the standard material was within $100 \pm 10 \%$. Bioavailable fractions of $\mathrm{Cu}, \mathrm{Zn}, \mathrm{Pb}$, and $\mathrm{Cd}$ in soils were extracted using a solution containing $0.05 \mathrm{~mol}^{-1}$ DTPA (diethylene triamine pentaacetic acid), $0.01 \mathrm{~mol} \mathrm{l}^{-1} \quad \mathrm{CaCl}_{2}$, and $0.1 \mathrm{~mol}^{-1}$ TEA (triethanolamine) at $\mathrm{pH} 7.30$ (Gupta and Sinha 2006) and were determined by ICP-AES. Plant available P was extracted by $0.5 \mathrm{~mol}^{-1} \mathrm{NaHCO}_{3}$ solution and determined colorimetrically by the vanadomolybdate method. In all treatments, basal nutrients in solution were mixed with the soil. The nutrients were added to 
the soil at rates of $684 \mathrm{mg} \mathrm{N}\left(\mathrm{NH}_{4} \mathrm{NO}_{3}\right), 300 \mathrm{mg} \mathrm{K}$ $\left(\mathrm{K}_{2} \mathrm{SO}_{4}\right), 180 \mathrm{mg} \mathrm{Mg}\left(\mathrm{MgSO}_{4}\right)$, and $300 \mathrm{mg} \mathrm{Ca}$ $\left(\mathrm{CaCl}_{2}\right) \mathrm{kg}^{-1}$.

\section{AMF isolates}

The leguminous plants were inoculated with Glomus mosseae (BGC, $\mathrm{XJ} 01$ ) isolates (+AMF treatment) or left uninoculated ( $-\mathrm{AMF}$ treatment). The inoculum of G. mosseae, obtained from the Beijing Academy of Agriculture and Forestry, China, contained dried roots of grain sorghum, hyphae, and spores.

Seeds of $S$. rostrata, S. cannabina, $M$. sativa and their inoculants

Strains of A. caulinodans (ACCC 19502) and seeds of M. sativa and its inoculant (Rhizobium meliloti) were obtained from the Chinese Academy of Agricultural Sciences (CAAS). Seeds of $S$. rostrata were purchased from AgroForestor (UK). Seeds of S. cannabina were collected from Zhengzhou, Henan Province, China, and its inoculant (Rhizobium spp.) was obtained from CAAS.

Plant growth conditions

Seeds of Sesbania rostrata, Sesbania cannabina, and Medicago sativa were surface-sterilized with $10 \%$ (v/ v) $\mathrm{H}_{2} \mathrm{O}_{2}$ for $10 \mathrm{~min}$ and washed with tap water and then deionized water. After being immersed in deionized water for $24 \mathrm{~h}$, the seeds were allowed to germinate on moist filter paper. When the radicles appeared, uniform seedlings were selected for the experiment. The seedlings were grown in $500 \mathrm{~g}$ plastic pots containing $460 \mathrm{~g}$ of soil plus $40 \mathrm{~g}$ of inoculum for the +AMF treatment, or $460 \mathrm{~g}$ of soil plus $40 \mathrm{~g}$ of sterilized inoculum for the -AMF treatment. The AMF inocula were fully mixed with the soil. The plastic pots of both treatments of +AMF and -AMF for Sesbania rostrata, Sesbania cannabina, and Medicago sativa were inoculated with A. caulinodans, Rhizobium spp., and Rhizobium meliloti, respectively. The soil moisture was maintained at $70 \%$ of field water holding capacity by adding appropriate amounts of deionized water. Each treatment had four replicates. The containers were arranged using a random block design in a temperature-controlled $\left(20 \pm 5^{\circ} \mathrm{C}\right)$ growth chamber for 6 weeks with a $14 \mathrm{~h}$ photoperiod at $280 \mu \mathrm{mol} \mathrm{m} \mathrm{m}^{-2} \mathrm{~s}^{-1}$ and relative humidity of $70 \%$.

Plant harvest

The plants were harvested after 6 weeks of growth. After the shoots were cut off, the roots were carefully washed free of soil with tap water, fully rinsed in deionized water, and then washed with $1 \mathrm{mmol}^{-1}$ $\mathrm{CaCl}_{2}$ solution for $30 \mathrm{~min}$ to remove all the particles that had adhered to the root surface and to desorb metals associated with cell walls. The root nodules were visually counted.

Root colonization

The clean roots were cut into segments of about $1 \mathrm{~cm}$ in length. A randomly selected fresh root subsample of about $1 \mathrm{~g}$ was taken for the assessment of root colonization. The roots were cleaned in $10 \% \mathrm{KOH}$, stained with $0.05 \%$ trypan blue (Phillips and Hayman 1970). The percent colonization was then determined by the grid intersect method (Giovannetti and Mosse 1980).

Plant biomass determination and HMs analysis

After being dried at $70^{\circ} \mathrm{C}$ for $72 \mathrm{~h}$, the dry weights of the shoots and roots were determined, and the samples were ground with a stainless steel mill. The plant materials were then digested using conc. $\mathrm{H}_{2} \mathrm{SO}_{4}+\mathrm{H}_{2} \mathrm{O}_{2}$ with an open-vessel method at $300^{\circ} \mathrm{C}$, and the concentrations of $\mathrm{Cu}, \mathrm{Zn}, \mathrm{Pb}, \mathrm{Cd}$, and $\mathrm{P}$ were determined by ICP-AES, while the $\mathrm{N}$ concentration was determined by the Kjeldahl nitrogen method (Lowther 1980). A standard plant material (GBW07602) from the Department of Earth and Mines of China was used to verify the accuracy of metal determination. The recovery rates for all heavy metals $(\mathrm{Cu}, \mathrm{Zn}, \mathrm{Pb}, \mathrm{Cd}), \mathrm{N}$, and $\mathrm{P}$ were within $90 \pm 10 \%$.

\section{Data analysis}

Results are presented as mean $\pm \mathrm{SE}$, and all data were subjected to multi-comparisons by the least significant difference (LSD) at the 5\% level using GenStat for PC/Windows 6.1 GenStat (Payne 2002). 
Table 1 Root colonization (\%) and nodule numbers of three leguminous plants (mean $\pm \mathrm{SE}, n=4$ )

\begin{tabular}{llrlrr}
\hline Plants & \multicolumn{2}{l}{ Root colonization } & & \multicolumn{2}{l}{ Nodule numbers } \\
\cline { 2 - 3 } \cline { 6 - 6 } & - AMF & +AMF & & - AMF & +AMF \\
\hline M. sativa & $0 \mathrm{c}$ & $35 \pm 2 \mathrm{~b}$ & & $0 \mathrm{~d}$ & $1 \pm 2 \mathrm{bc}$ \\
S. rostrata & $0 \mathrm{c}$ & $66 \pm 2 \mathrm{a}$ & & $2 \pm 1 \mathrm{c}$ & $6 \pm 2 \mathrm{~b}$ \\
S. cannabina & $0 \mathrm{c}$ & $42 \pm 5 \mathrm{~b}$ & & $0 \mathrm{~d}$ & $12 \pm 1 \mathrm{a}$ \\
\hline
\end{tabular}

-AMF and +AMF represent uninoculated treatment and inoculation with Glomus mosseae, respectively. Different letters in the same group (root colonization or nodule numbers) indicate significant differences between inoculation treatments and uninoculated treatment by LSD multi-comparison at the 5\% level

\section{Results}

Concentrations of heavy metals in the soil

The concentrations of $\mathrm{Cu}, \mathrm{Zn}, \mathrm{Pb}$, and $\mathrm{Cd}$ in the soil were $1,481,2,286,388$, and $1.6 \mathrm{mg} \mathrm{kg}^{-1}$, respectively, and $150,93,45 \mathrm{mg} \mathrm{kg}^{-1}$ of $\mathrm{Cu}, \mathrm{Zn}$, and $\mathrm{Pb}$ in the soil was bioavailable (DTPA-extractable), indicating that the soil was highly contaminated by these metals.

Root colonization and root nodule number of different leguminous plants

No root colonization by G. mosseae was detected in the -AMF treatments, and under the +AMF treatments $S$. rostrata had the highest root colonization among the three legumes $(P<0.05)$ (Table 1$)$. Root nodules were only detected in $S$. rostrata under the - AMF treatments. The +AMF treatments significantly enhanced the development of root nodules compared with the - AMF treatments $(P<0.05)$, and $S$. rostrata developed more nodules than the other leguminous plants (Table 1).

Plant biomass

Compared with the -AMF treatments, the +AMF treatments significantly enhanced the shoot and root biomass of all plants $(P<0.05)$. The shoot and root biomasses of $S$. rostrata were the highest among the three plants irrespective of the inoculation by G. mosseae (Fig. 1).

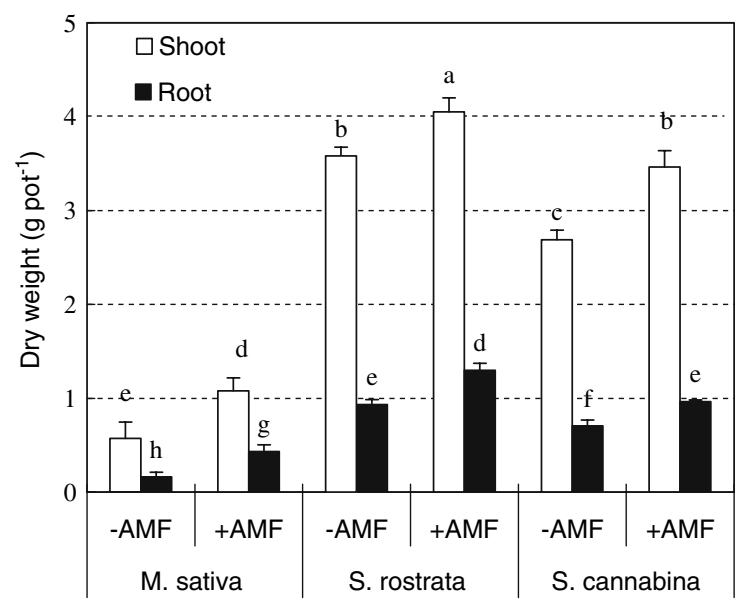

Fig. 1 The effects of AMF on shoot and root dry weights of three leguminous plants with and without AMF. - AMF and + AMF represent uninoculated treatment and inoculation treatment with Glomus mosseae, respectively. By analysis of variance, dry weights and inoculation were significant $(P<0.05)$ for both shoot and roots of all plants. The letters above the columns indicate significant differences between inoculation and uninoculated treatments by LSD multi-comparison at the $5 \%$ level

\section{Concentrations of $\mathrm{N}$ and $\mathrm{P}$ in plant tissues}

The concentrations of $\mathrm{N}$ and $\mathrm{P}$ in the plants after 6 weeks varied among plant species and treatments (Table 2). In the -AMF and +AMF plants, the N concentrations in both shoots and roots increased in the following order: $S$. cannabina $<S$. rostrata $<M$. sativa. In the $-\mathrm{AMF}$ plants, the $\mathrm{P}$ concentrations in the roots increased in the same order, but the $\mathrm{P}$ concentrations in the shoots of $S$. rostrata were higher than those in $M$. sativa and $S$. cannabina $(P<0.05)$. Compared with the $-\mathrm{AMF}$ treatments, colonization by G. mosseae significantly decreased the N concentrations in the shoots and the $\mathrm{P}$ concentrations in the roots of $M$. sativa. The concentrations of $\mathrm{N}$ and $\mathrm{P}$ in the shoots and roots of the Sesbania plants were increased by the colonization of AMF $(P<0.05)$.

Total $\mathrm{N}$ and $\mathrm{P}$ uptakes by three leguminous plants

Both Sesbania species showed higher capacity for N and $\mathrm{P}$ uptakes than $M$. sativa (Table 2), which was largely due to the fact that the biomasses of the Sesbania plants were larger than those of $M$. sativa. The $\mathrm{N}$ uptakes in the shoots and roots of $S$. rostrata were higher than those of $S$. cannabina $(P<0.05)$. The 
Table 2 The effects of AMF on the concentrations $\left(\mathrm{mg} \mathrm{kg}^{-1}\right)$ and uptake $\left(\mathrm{mg} \mathrm{pot}^{-1}\right)$ of $\mathrm{N}$ and $\mathrm{P}$ in three leguminous plants $($ mean $\pm \mathrm{SE}, n=4)$

\begin{tabular}{|c|c|c|c|c|c|c|}
\hline \multicolumn{2}{|c|}{ Plant species } & \multirow[t]{2}{*}{ Treatment } & \multicolumn{2}{|c|}{ Nutrient concentration } & \multicolumn{2}{|l|}{ Nutrient uptake } \\
\hline & & & $\mathrm{N}$ & $\mathrm{P}$ & $\mathrm{N}$ & $\mathrm{P}$ \\
\hline \multirow[t]{6}{*}{ Shoot } & \multirow[t]{2}{*}{ M. sativa } & $-\mathrm{AMF}$ & $4.06 \pm 0.16 \mathrm{a}$ & $1,215.4 \pm 23.4 \mathrm{~g}$ & $14.07 \pm 0.64 \mathrm{f}$ & $497.5 \pm 94.4 \mathrm{~g}$ \\
\hline & & $+\mathrm{AMF}$ & $3.26 \pm 0.08 b$ & $1,081.0 \pm 37.3 \mathrm{~g}$ & $35.06 \pm 4.23 \mathrm{~d}$ & $1,338.8 \pm 119.1 \mathrm{e}$ \\
\hline & \multirow[t]{2}{*}{ S. rostrata } & $-\mathrm{AMF}$ & $1.76 \pm 0.06 \mathrm{e}$ & $1,297.1 \pm 2.6 \mathrm{f}$ & $62.80 \pm 1.48 \mathrm{~b}$ & $4,415.6 \pm 233.5 b$ \\
\hline & & $+\mathrm{AMF}$ & $2.54 \pm 0.06 \mathrm{c}$ & $2,494.5 \pm 51.0 \mathrm{~b}$ & $108.96 \pm 1.04 \mathrm{a}$ & $5,865.0 \pm 355.6 \mathrm{a}$ \\
\hline & \multirow[t]{2}{*}{ S. cannabina } & $-\mathrm{AMF}$ & $1.40 \pm 0.04 \mathrm{f}$ & $1,139.8 \pm 15.1 \mathrm{~g}$ & $37.40 \pm 0.92 \mathrm{~d}$ & $2,989.1 \pm 166.6 \mathrm{c}$ \\
\hline & & $+\mathrm{AMF}$ & $1.68 \pm 0.07 \mathrm{e}$ & $1,350.6 \pm 98.3$ ef & $58.09 \pm 0.87 \mathrm{c}$ & $4,803.8 \pm 374.9 b$ \\
\hline \multirow[t]{6}{*}{ Root } & \multirow[t]{2}{*}{ M. sativa } & $-\mathrm{AMF}$ & $2.84 \pm 0.36 \mathrm{~b}$ & $3,238.4 \pm 40.6 \mathrm{a}$ & $3.84 \pm 0.42 \mathrm{~h}$ & $421.4 \pm 46.1 \mathrm{~g}$ \\
\hline & & $+\mathrm{AMF}$ & $3.16 \pm 0.26 \mathrm{~b}$ & $2,152.8 \pm 26.8 \mathrm{c}$ & $13.21 \pm 1.32 \mathrm{f}$ & $898.8 \pm 39.5 \mathrm{f}$ \\
\hline & \multirow[t]{2}{*}{ S. rostrata } & $-\mathrm{AMF}$ & $1.34 \pm 0.06 \mathrm{~g}$ & $2,161.0 \pm 24.5 \mathrm{c}$ & $12.49 \pm 0.72 \mathrm{f}$ & $1,237.1 \pm 62.2 \mathrm{e}$ \\
\hline & & $+\mathrm{AMF}$ & $2.07 \pm 0.04 \mathrm{c}$ & $2,618.1 \pm 74.2 \mathrm{a}$ & $26.75 \pm 1.13 \mathrm{e}$ & $1,727.7 \pm 91.3 \mathrm{~d}$ \\
\hline & \multirow[t]{2}{*}{ S. cannabina } & $-\mathrm{AMF}$ & $1.07 \pm 0.07 \mathrm{~h}$ & $1,563.5 \pm 104.1 \mathrm{e}$ & $7.50 \pm 0.50 \mathrm{~g}$ & $967.8 \pm 117.9 \mathrm{f}$ \\
\hline & & $+\mathrm{AMF}$ & $1.33 \pm 0.02 \mathrm{~g}$ & $2,000.2 \pm 59.8 \mathrm{~d}$ & $12.83 \pm 0.14 \mathrm{f}$ & $1,647.3 \pm 189.4 \mathrm{de}$ \\
\hline
\end{tabular}

-AMF and +AMF represent uninoculated treatment and inoculation with Glomus mosseae, respectively. Different letters in the same column indicate significant differences between inoculation treatments and uninoculated treatment by LSD multi-comparison at the 5\% level

colonization by G. mosseae significantly increased $\mathrm{N}$ and $\mathrm{P}$ uptakes of the roots and shoots of the three plants $(P<0.05)$.

Concentrations of $\mathrm{Cu}, \mathrm{Zn}, \mathrm{Pb}$, and $\mathrm{Cd}$ in the plant tissues

The three leguminous plants showed significant differences in heavy metal concentrations in their tissue (Table 3). The concentrations of $\mathrm{Cu}, \mathrm{Zn}, \mathrm{Pb}$, and $\mathrm{Cd}$ in the roots were significantly higher $(P<0.05)$ than those in the shoots of all three plants. In the -AMF plants, the concentrations of $\mathrm{Cu}$ and $\mathrm{Cd}$ in the shoots of $S$. rostrata were significantly higher $(P<0.05)$ than those of $S$. cannabina and $M$. sativa. The $\mathrm{Zn}$ concentrations in both Sesbania plants were significantly higher than those of $M$. sativa $(P<0.05)$, and the $\mathrm{Pb}$ concentrations in the shoots of $S$. cannabina were significantly higher than those of $S$. rostrata and $M$. sativa $(P<0.05)$. Compared with the - AMF treatments, colonization by $G$. mosseae decreased the $\mathrm{Cu}$ concentrations in the shoots of all species tested and the $\mathrm{Pb}$ concentrations in the shoots of $M$. sativa and $S$. cannabina $(P<0.05)$, but increased the Cd concentrations in the shoots of $M$. sativa and S. cannabina $(P<0.05)$. Compared with the $-\mathrm{AMF}$ treatments, colonization by $G$. mosseae significantly increased the $\mathrm{Cu}$ and $\mathrm{Zn}$ concentrations in the roots of $S$. cannabina and M. sativa; however, it decreased the $\mathrm{Cu}$ and $\mathrm{Zn}$ concentrations in the roots of $S$. rostrata $(P<0.05)$. The +AMF treatments decreased the $\mathrm{Pb}$ and $\mathrm{Cd}$ concentrations in the roots of $M$. sativa compared with those of the $-\mathrm{AMF}$ treatments $(P<0.05)$, while the $\mathrm{Cu}$ and $\mathrm{Zn}$ concentrations in the roots of $S$. rostrata were significantly increased $(P<0.05)$.

$\mathrm{Cu}, \mathrm{Zn}, \mathrm{Pb}$, and $\mathrm{Cd}$ uptake by the leguminous plants

Under both the $-\mathrm{AMF}$ and +AMF treatments, the accumulation of $\mathrm{Cu}, \mathrm{Zn}, \mathrm{Pb}$, and $\mathrm{Cd}$ in the shoots of both Sesbania plants was significantly higher than that in the shoots of $M$. sativa $(P<0.05)$ (Table 4$)$. Under the -AMF treatments, the $\mathrm{Cu}$ accumulation in the shoots of $S$. rostrata was higher than that in the shoots of $S$. cannabina, while the $\mathrm{Pb}$ accumulation in the shoots of $S$. rostrata was less than that in the shoots of $S$. cannabina $(P<0.05)$. The AMF colonization increased the uptakes of $\mathrm{Cu}, \mathrm{Zn}, \mathrm{Pb}$, and $\mathrm{Cd}$ in the roots of the three plants except for $\mathrm{Cu}$ in $S$. rostrata and $\mathrm{Pb}$ in $S$. cannabina $(P<0.05)$ compared with -AMF treatments (Table 4).

Root/shoot ratios of $\mathrm{Cu}, \mathrm{Zn}, \mathrm{Pb}$, and $\mathrm{Cd}$ in plants

There were significant differences in the root/shoot ratios of $\mathrm{Cu}, \mathrm{Zn}, \mathrm{Pb}$, and $\mathrm{Cd}$ in the three leguminous 
Table 3 The effects of AMF on the concentrations $\left(\mathrm{mg} \mathrm{kg}^{-1}\right)$ of $\mathrm{Cu}, \mathrm{Zn}, \mathrm{Pb}$, and $\mathrm{Cd}$ in three leguminous plants (mean $\left.\pm \mathrm{SE}, n=4\right)$

\begin{tabular}{|c|c|c|c|c|c|c|}
\hline Plant species & & Treatment & $\mathrm{Cu}$ & $\mathrm{Zn}$ & $\mathrm{Cd}$ & $\mathrm{Pb}$ \\
\hline \multirow[t]{4}{*}{ M. sativa } & \multirow[t]{2}{*}{ Shoot } & $-\mathrm{AMF}$ & $21.7 \pm 2.5 \mathrm{~h}$ & $64.4 \pm 9.1 \mathrm{~g}$ & $5.0 \pm 0.1 \mathrm{~h}$ & $7.9 \pm 0.1 \mathrm{f}$ \\
\hline & & $+\mathrm{AMF}$ & $9.8 \pm 0.2 \mathrm{j}$ & $78.1 \pm 3.9 \mathrm{~g}$ & $5.4 \pm 0.2 \mathrm{~g}$ & $7.3 \pm 0.1 \mathrm{~g}$ \\
\hline & \multirow[t]{2}{*}{ Root } & $-\mathrm{AMF}$ & $247 \pm 5.8 \mathrm{~d}$ & $394 \pm 51.0 \mathrm{~b}$ & $26.1 \pm 2.5 \mathrm{a}$ & $95.7 \pm 6.5 \mathrm{a}$ \\
\hline & & $+\mathrm{AMF}$ & $785 \pm 9.1 \mathrm{a}$ & $717 \pm 51.4 \mathrm{a}$ & $19.7 \pm 2.6 \mathrm{~b}$ & $62.4 \pm 1.9 b$ \\
\hline \multirow[t]{4}{*}{ S. rostrata } & \multirow[t]{2}{*}{ Shoot } & $-\mathrm{AMF}$ & $43.6 \pm 1.5 \mathrm{~g}$ & $108.2 \pm 7.3 \mathrm{~d}$ & $7.2 \pm 0.2 \mathrm{f}$ & $7.0 \pm 0.1 \mathrm{~h}$ \\
\hline & & $+\mathrm{AMF}$ & $24.6 \pm 0.7 \mathrm{~h}$ & $93.4 \pm 2.4 \mathrm{f}$ & $7.2 \pm 0.1 \mathrm{f}$ & $7.4 \pm 0.1 \mathrm{~g}$ \\
\hline & \multirow[t]{2}{*}{ Root } & $-\mathrm{AMF}$ & $377 \pm 5.6 b$ & $418 \pm 1.7 \mathrm{~b}$ & $13.1 \pm 0.3 \mathrm{~d}$ & $36.4 \pm 0.5 \mathrm{~d}$ \\
\hline & & $+\mathrm{AMF}$ & $307 \pm 3.1 \mathrm{c}$ & $351 \pm 3.1 \mathrm{c}$ & $14.5 \pm 0.6 \mathrm{c}$ & $41.4 \pm 0.3 \mathrm{c}$ \\
\hline \multirow[t]{4}{*}{ S. cannabina } & \multirow[t]{2}{*}{ Shoot } & $-\mathrm{AMF}$ & $24.8 \pm 1.7 \mathrm{~h}$ & $105 \pm 3.1 \mathrm{~d}$ & $5.7 \pm 0.1 \mathrm{~g}$ & $9.1 \pm 0.8 \mathrm{f}$ \\
\hline & & $+\mathrm{AMF}$ & $12.5 \pm 0.7 \mathrm{i}$ & $104 \pm 2.2 \mathrm{f}$ & $6.7 \pm 0.5 \mathrm{f}$ & $7.5 \pm 0.1 \mathrm{~g}$ \\
\hline & \multirow[t]{2}{*}{ Root } & $-\mathrm{AMF}$ & $124 \pm 4.0 \mathrm{f}$ & $189 \pm 0.8 \mathrm{~d}$ & $9.2 \pm 0.1 \mathrm{e}$ & $22.2 \pm 0.1 \mathrm{e}$ \\
\hline & & $+\mathrm{AMF}$ & $213 \pm 7.6 \mathrm{e}$ & $229 \pm 19.9 \mathrm{~d}$ & $11.9 \pm 1.3 \mathrm{~d}$ & $20.8 \pm 0.5 \mathrm{e}$ \\
\hline
\end{tabular}

$-\mathrm{AMF}$ and +AMF represent uninoculated treatment and inoculation with Glomus mosseae, respectively. Different letters in the same column indicate significant differences between inoculation treatments and uninoculated treatment by LSD multi-comparison at the 5\% level

Table 4 The effects of AMF on uptake $\left(\mu \mathrm{g} \operatorname{pot}^{-1}\right)$ of $\mathrm{Cu}, \mathrm{Zn}, \mathrm{Pb}$, and $\mathrm{Cd}$ by three leguminous plants (mean $\left.\pm \mathrm{SE}, n=4\right)$

\begin{tabular}{|c|c|c|c|c|c|c|}
\hline Plant species & & Treatment & $\mathrm{Cu}$ & $\mathrm{Zn}$ & $\mathrm{Cd}$ & $\mathrm{Pb}$ \\
\hline \multirow[t]{4}{*}{ M. sativa } & \multirow[t]{2}{*}{ Shoot } & $-\mathrm{AMF}$ & $7.4 \pm 0.6 \mathrm{i}$ & $28.0 \pm 3.2 \mathrm{j}$ & $2.1 \pm 0.3 \mathrm{i}$ & $3.1 \pm 0.5 \mathrm{~g}$ \\
\hline & & $+\mathrm{AMF}$ & $10.5 \pm 1.1 \mathrm{~h}$ & $73.3 \pm 9.1 \mathrm{~h}$ & $5.2 \pm 0.6 \mathrm{~g}$ & $8.7 \pm 0.8 \mathrm{f}$ \\
\hline & \multirow[t]{2}{*}{ Root } & $-\mathrm{AMF}$ & $39.6 \pm 11.4 \mathrm{~g}$ & $45.5 \pm 6.0 \mathrm{i}$ & $3.3 \pm 0.4 \mathrm{~h}$ & $10.8 \pm 1.0 \mathrm{e}$ \\
\hline & & $+\mathrm{AMF}$ & $339 \pm 56.2 \mathrm{a}$ & $309 \pm 47.1 \mathrm{bc}$ & $10.9 \pm 0.8 \mathrm{ce}$ & $31.8 \pm 5.3 \mathrm{a}$ \\
\hline \multirow[t]{4}{*}{ S. rostrata } & \multirow[t]{2}{*}{ Shoot } & $-\mathrm{AMF}$ & $156.2 \pm 7.9 \mathrm{c}$ & $284 \pm 31.2 \mathrm{~cd}$ & $16.9 \pm 0.8 \mathrm{~b}$ & $17.0 \pm 1.5 \mathrm{c}$ \\
\hline & & $+\mathrm{AMF}$ & $105.3 \pm 1.7 \mathrm{~d}$ & $311 \pm 8.6 \mathrm{bd}$ & $22.0 \pm 1.5 \mathrm{a}$ & $23.4 \pm 1.3 \mathrm{~b}$ \\
\hline & \multirow[t]{2}{*}{ Root } & $-\mathrm{AMF}$ & $353 \pm 24.0 \mathrm{a}$ & $161 \pm 8.5 \mathrm{f}$ & $5.8 \pm 0.4 \mathrm{~g}$ & $17.4 \pm 1.1 \mathrm{c}$ \\
\hline & & $+\mathrm{AMF}$ & $399 \pm 21.3 \mathrm{a}$ & $209 \pm 6.9 \mathrm{e}$ & $8.9 \pm 0.3 \mathrm{~d}$ & $25.8 \pm 0.4 \mathrm{ab}$ \\
\hline \multirow[t]{4}{*}{ S. cannabina } & \multirow[t]{2}{*}{ Shoot } & $-\mathrm{AMF}$ & $67.0 \pm 6.7 \mathrm{f}$ & $285 \pm 1.3 \mathrm{c}$ & $15.5 \pm 0.3 b$ & $28.6 \pm 0.8 \mathrm{a}$ \\
\hline & & $+\mathrm{AMF}$ & $43.2 \pm 1.7 \mathrm{~g}$ & $373 \pm 19.4 \mathrm{a}$ & $23.1 \pm 1.7 \mathrm{a}$ & $24.4 \pm 0.7 \mathrm{~b}$ \\
\hline & \multirow[t]{2}{*}{ Root } & $-\mathrm{AMF}$ & $87.8 \pm 7.7$ e & $121 \pm 11.4 \mathrm{~g}$ & $6.8 \pm 0.1 \mathrm{f}$ & $16.4 \pm 0.1 \mathrm{~d}$ \\
\hline & & $+\mathrm{AMF}$ & $205 \pm 10.1 b$ & $174 \pm 20.7 \mathrm{f}$ & $8.8 \pm 1.4 \mathrm{de}$ & $13.9 \pm 1.6 \mathrm{e}$ \\
\hline
\end{tabular}

-AMF and +AMF represent uninoculated treatment and inoculation with Glomus mosseae, respectively. Different letters in the same column indicate significant differences between inoculation treatments and uninoculated treatment by LSD multi-comparison at the 5\% level

plants (Table 5). Under both treatments (+AMF and -AMF), $M$. sativa translocated less $\mathrm{Cu}, \mathrm{Zn}, \mathrm{Pb}$, and Cd than $S$. rostrata and $S$. cannabina $(P<0.05)$. Compared with the -AMF treatments, the root/shoot ratios of $\mathrm{Cu}$ and $\mathrm{Zn}$ in $M$. sativa were significantly increased by the colonization of $G$. mosseae $(P<0.05)$. The + AMF treatments increased the root/ shoot ratios of $\mathrm{Cu}$ in both Sesbania plants $(P<0.05)$, and no significant differences in the root/shoot ratios of $\mathrm{Zn}, \mathrm{Pb}$, and $\mathrm{Cd}$ were found between the +AMF and -AMF treatments.

\section{Discussion}

Effects of AMF colonization on nutrient accumulation by different species of legumes

Under + AMF and - AMF treatments, the biomass of $S$. rostrata was significantly higher than that of $S$. cannabina and $M$. sativa, which might be attributed to the higher capacity of $\mathrm{N}$ accumulation. On one hand, the capacity for $\mathrm{N}_{2}$-fixation of $S$. rostrata was higher and the stem nodules might be efficient in $\mathrm{N}_{2}$-fixation 
Table $5 \mathrm{Root} / \mathrm{shoot}$ ratios of $\mathrm{Cu}, \mathrm{Zn}, \mathrm{Pb}$ and $\mathrm{Cd}$ in the three leguminous plants (mean $\pm \mathrm{SE}, n=4$ )

\begin{tabular}{llllll}
\hline Plants & Treatments & $\mathrm{Cu}$ & $\mathrm{Zn}$ & $\mathrm{Pb}$ & $\mathrm{Cd}$ \\
\hline M. sativa & - AMF & $5.2 \pm 1.2 \mathrm{~b}$ & $1.7 \pm 0.3 \mathrm{~b}$ & $3.6 \pm 0.5 \mathrm{a}$ & $1.6 \pm 0.2 \mathrm{a}$ \\
& + AMF & $31.9 \pm 2.4 \mathrm{a}$ & $4.4 \pm 1.0 \mathrm{a}$ & $3.6 \pm 0.3 \mathrm{a}$ & $2.2 \pm 0.3 \mathrm{a}$ \\
S. rostrata & - AMF & $2.3 \pm 0.3 \mathrm{~d}$ & $0.6 \pm 0.0 \mathrm{c}$ & $1.0 \pm 0.1 \mathrm{~b}$ & $0.3 \pm 0.0 \mathrm{~b}$ \\
& + AMF & $3.8 \pm 0.2 \mathrm{c}$ & $0.7 \pm 0.0 \mathrm{c}$ & $1.1 \pm 0.1 \mathrm{~b}$ & $0.4 \pm 0.0 \mathrm{~b}$ \\
S. cannabina & -AMF & $1.3 \pm 0.1 \mathrm{~d}$ & $0.4 \pm 0.0 \mathrm{c}$ & $0.6 \pm 0.0 \mathrm{c}$ & $0.4 \pm 0.0 \mathrm{~b}$ \\
& + AMF & $4.8 \pm 0.2 \mathrm{bc}$ & $0.5 \pm 0.1 \mathrm{c}$ & $0.6 \pm 0.1 \mathrm{c}$ & $0.4 \pm 0.1 \mathrm{~b}$ \\
\hline
\end{tabular}

-AMF and +AMF represent uninoculated treatment and inoculation with Glomus mosseae, respectively. Different letters in the same column indicate significant differences between inoculation treatments and uninoculated treatment by LSD multi-comparison at the 5\% level

(Ye et al. 2001b; Chan et al. 2003; Ma et al. 2006). On the other hand, the soil was contaminated by heavy metals, which could inhibit the development of root nodules directly exposed to the soil, making the stem nodules more important. This is similar to previous results reported by Ye et al. (2001b) who reported that stem nodules significantly increased $\mathrm{N}$ accumulation, especially under stress from metal contamination.

The growth of all of the plants in the present study was increased by AMF colonization, indicating that AMF colonization increased the plants' tolerance to metals. In addition to the increased $\mathrm{P}$ accumulation, AMF colonization stimulated the formation of root nodules, especially in $S$. rostrata and $S$. cannabina, indicating that better P nutrition in $S$. rostrata could also contribute to better $\mathrm{N}$ nutrition by stimulating the development of root nodules of $S$. rostrata (Toro et al. 1998). The higher numbers of root nodules under the +AMF treatments led to higher $\mathrm{N}$ accumulation in the plants compared with the $-\mathrm{AMF}$ treatments. Andrade et al. (2004) also reported that inoculation by Glomus macrocarpum increased root nodule numbers of soybean plants, which then attributed to better $P$ nutrition in mycorrhizal plants. $\mathrm{P}$ is a key element in forming root nodules, and therefore the AMF colonization is beneficial to the development of root nodules (Barea et al. 2005). It was also reported by Chen et al. (1999) that AMF could increase N accumulation in mycorrhizal plants because of higher nitrogenasefixation activity in mycorrhizal plants and consequently increased efficiency of $\mathrm{N}_{2}$-fixation.

Effects of AMF colonization on accumulation of $\mathrm{Cu}$, $\mathrm{Zn}, \mathrm{Pb}$, and $\mathrm{Cd}$ by different species of legumes

Not only were the legumes nutrient uptakes affected by the AMF colonization, but their metal accumula- tions were also affected, which changed the plants' tolerance to metal contamination. In addition to the better nutrient uptake, Ibekwe et al. (1995) suggested that the tolerance of $S$. rostrata to heavy metals was significantly enhanced via development of a symbiotic relationship between the roots and rhizobium since rhizobium showed less sensitivity to $\mathrm{Zn}$ and $\mathrm{Cd}$ than plants. In the present experiment, the biomasses of the three legumes and root nodules developed were increased by AMF colonization, possibly due to the fact that the microbial cooperation in the rhizosphere could increase the resistance of the host plant to the toxicity of heavy metals. Rhizobium infected the cells and adsorbed heavy metals, decreasing the influx of heavy metals into protoplasts of roots and thereby enhancing the tolerance of the host plant to metals (Kotrba et al. 1999).

Heavy metal accumulation was different among the legume species, and inoculation by G. mosseae yielded different effects on the accumulations of $\mathrm{Cu}, \mathrm{Zn}, \mathrm{Pb}$, and $\mathrm{Cd}$ by the three legumes in the present study. Compared with the -AMF treatment, the +AMF treatments significantly increased the total metal accumulation in the shoots of $S$. rostrata except for $\mathrm{Cu}$, but no significant increases in the concentrations of the heavy metals except for $\mathrm{Pb}$ were found. Compared with the $-\mathrm{AMF}$ treatments, $+\mathrm{AMF}$ significantly enhanced the biomass of $M$. sativa, indicating that AMF could also decrease toxicity of heavy metals in $M$. sativa by dilution. In contrast, $\mathrm{AMF}$ decreased the $\mathrm{Cu}$ accumulation in $S$. rostrata as well as the $\mathrm{Cu}$ concentrations, indicating that AMF could alleviate the $\mathrm{Cu}$ toxicity to $S$. rostrata in a different way from that of $\mathrm{Pb}$ and $\mathrm{Cd}$ by reducing the $\mathrm{Cu}$ uptake. Therefore, in this study, the mechanisms by which AMF improved the resistance of the plants to different metals were different. 
It was reported that AMF could immobilize heavy metals in special parts of the roots or in the hyphal structure to reduce the toxicity of metal to plants (Zhang et al. 2005). Compared with the -AMF treatments, the root/shoot ratios of $\mathrm{Cu}$ in the three legumes and root/shoot ratios of $\mathrm{Zn}$ in $M$. sativa were significantly increased under the +AMF treatments, indicating that compartmentation was also one of the resistance mechanisms of $M$. sativa to heavy metals. According to Andrade (2002), acidic polysaccharides found in the cell wall of algae have been associated with the capacity of these organisms to accumulate heavy metals when exposed to high concentrations of heavy metals, indicating that cell walls play an important role in alleviating metal toxicity. AMF might change the components of root cell walls, thus increasing the adsorption capacity to metals, such as $\mathrm{Cu}$ (data not shown). The mechanisms to resist heavy metals induced by the same AMF were different because of the different plant species and different metals.

\section{Conclusion}

We found that the interaction between AMF and rhizobium increased plant growth in soil contaminated by heavy metals by increasing both the plant nutrient uptake and tolerance to multi-metals. AMF colonization enabled the plants to accumulate more $\mathrm{P}$, consequently stimulating root nodules and increasing $\mathrm{N}$ accumulation. Besides plant nutrient improvement, AMF increased plant tolerance to metals via such mechanisms as dilution effects, increased tolerance to metals, decreased metal uptake, and translocation from root to shoot. These mechanisms could be utilized in phytoremediation or ecological restoration.

Acknowledgements This work was financially supported by the Research Grants Council (HKBU2181/03M), Hong Kong, China, the Ministry of Science and Technology (2002CB410808), China and the Young Scholars Fund of Beijing University of Chemical Technology, China (QN0603).

\section{References}

Andrade, M. R., Farina, M., \& Amado Filho, G. M. (2002). Role of Padina gymnospora (Dictyotales, Phaeophyceae) call walls in cadmium accumulation. Phycologia, 41, 39-48.
Andrade, S. A. L., Abreu, C. A., de Abreu, M. F., \& Silveira, A. P. D. (2004). Influence of lead additions on arbuscular mycorrhiza and rhizobium symbioses under soybean plants. Applied Soil Ecology, 26, 123-131.

Barea, J. M., Pozo, M. J., Azcón, R., \& Azcón A. (2005). Microbial co-operation in the rhizosphere. Journal of Experimental Botany, 56, 1761-1778.

Chan, Y. S. G., Ye, Z. H., \& Wong, M. H. (2003). Comparison of four Sesbania species to remediate $\mathrm{Pb} / \mathrm{Zn}$ and $\mathrm{Cu}$ mine tailings. Environmental Management, 32, 246-251.

Chen, W., Bruhlmann, F., Richias, R. D., \& Mulchandani, A. (1999). Engineering of improved microbes and enzymes for bioremediation. Current Opinion in Biotechnology, 10, 137-141.

Cui, Y. J., Zhu, Y.-G., Zhai, R. H., Chen, D. Y., Huang, Y. Z., Qiu, Y., \& Liang, J. Z. (2004). Transfer of metals from soil to vegetables in an area near a smelter in Nanning, China. Environment International, 30, 785-791.

Gao, L., Miao, Z., Bai, Z., Zhou, X., Zhao, J., \& Zhu, Y. (1998). A case study of ecological restoration at the Xiaoyi Bauxite Mine, Shanxi Province, China. Ecological Engineering, $11,221-229$.

Giovannetti, M., \& Mosse, B. (1980). An evaluation of techniques for measuring vesicular-arbuscular mycorrhizal infection in roots. New Phytologist, 84, 489-500.

Gupta, A. K., \& Sinha, S. (2006). Chemical fractionation and heavy metal accumulation in the plant of Sesamum indicum (L.) var. T55 grown on soil amended with tannery sludge: Selection of single extractants. Chemosphere, 64, 161173.

Ibekwe, A. M., Angle, J. S., Chaney, R. L., \& Van-Berkum, P. (1995). Sewage sludge and heavy metal effects on nodulation and nitrogen fixation of legumes. Journal of Environmental Quality, 24,1199-1204.

Karandashov, V., \& Bucher, M. (2005). Symbiotic phosphate transport in arbuscular mycorrhizas. Trends in Plant Science, 10, 22-29.

Kotrba, P., Doleckova, L., Lorenzo, V., \& Rumi, T. (1999). Enhanced bioaccumulation of heavy metal ions by bacterial cells due to surface display of short metal binding peptides. Applied and Environmental Microbiology, 65, 1092-1098.

Liu, Y., Zhu, Y.-G., Chen, B. D., Christie, P., \& Li, X. L. (2005). Influence of the arbuscular mycorrhizal fungus Glomus mosseae on uptake of arsenate by the As hyperaccumulator fern Pteris vittata L. Mycorrhiza, 15, 187-192.

Lowther, J. R. (1980). Use of a single sulfuric acid-hydrogen peroxide digest for the analysis of Pinus radiata needles. Communications in Soil Science and Plant Analysis, 11, 175-188.

Ma, Y., Dickinson, N. M., \& Wong, M. H. (2006). Beneficial effects of earthworms and arbuscular mycorrhizal fungi on establishment of leguminous trees on $\mathrm{Pb} / \mathrm{Zn}$ mine tailings. Soil Biology \& Biochemistry, 38, 1403-1412.

Payne, R. W., (Ed.), (2002). The guide to GenStat Release 6.1Part 1: Syntax and data management. GenStat Committee. Hemel Hempstead, UK: VSN International.

Phillips, J. M., \& Hayman, D. S. (1970). Improved procedures for clearing roots and staining parasitic and vesicular arbuscular mycorrhizal fungi for rapid assessment of infection. Transactions of British Mycological Society, 55, 158-160. 
Pichtel, J., \& Salt, C. A. (1998). Vegetative growth and trace metal accumulation on metalliferous wastes. Journal of Environmental Quality, 27, 618-642.

Smith, S. E., \& Read, D. J. (1997). Mycorrhizal Simbiosis. London: Academic Press.

Tiemann, K. J., Gardea-Torresdey, J. L., Gamez, G., Dokken, K., Sias, S., Renner, M. W., Furenlid, L. R. (1999). Use of $\mathrm{X}$-ray absorption apectroscopy and esterification to investigate $\mathrm{Cr}$ (III) and $\mathrm{Ni}$ (II) ligands in Alfalfa biomass. Environmental Science \& Technology, 33, 150-154.

Tordoff, G. M., Baker, A. J. M., \& Willis, A. J. (2000). Current approaches to the revegetation and reclamation of metalliferous mine wastes. Chemosphere, 41, 219-228.

Toro, M., Azcón, R., \& Barea, J. M. (1998). The use of isotopic dilution techniques to evaluate the interactive effects of Rhizobium genotype, mycorrhiza fungi, phosphate-solubilizing Rhizobacteria and rock phosphate on nitrogen and phosphorus acquisition by Medicago sativa. New Phytologist, 138, 265-273.

Vogel-Mikuš, K., Drobne, D., \& Regvar, M. (2005). Zn, Cd and $\mathrm{Pb}$ accumulation and arbuscular mycorrhizal colonisation of pennycress Thlaspi praecox Wulf. (Brassicaceae) from the vicinity of a lead mine and smelter in Slovenia. Environmental Pollution, 133, 233-242.

Wong, M. H. (2003). Ecological restoration of mine degraded soils, with emphasis on metal contaminated soils. Chemosphere, 50, 775-780.

Yang, Z. Y., Yuan, J. G., Xin, G. R., Chang, H. T., \& Wong, M. H. (1997). Germination, growth and nodulation of Sesbania rostrata grown in $\mathrm{Pb} / \mathrm{Zn}$ tailings. Environmental Management, 21, 1-6.

Ye, Z. H., Wong J. W. C., Wong, M. H., Lan, C. Y., \& Baker, A. J. M. (2001a). Lime and pig manure as ameliorants for the revegetation on lead/zinc mine tailings, a greenhouse study. Bioresource Technology, 69, 35-45.

Ye, Z. H., Yang, Z. Y., Chan, G. Y. S., \& Wong, M. H. (2001b). Growth response of Sesbania rostrata and S. cannabina to sludge-amended lead/zinc mine tailings. Environment International, 26, 449-455.

Zhang, X. H., Zhu Y.-G., Chen, B. D., Lin, A. J., Smith, S. E., \& Smith, A. E. (2005). Arbuscular mycorrhizal fungi contribute to the resistance of upland rice to combined metal contamination of soil. Journal of Plant Nutrition, 28, 2065-2077. 